\section{Wybrane przykłady zastosowania zieleni i wody jako naturalnych elementów przestrzeni poprawiających warunki lokalnych klimatów}

\author{
Selected examples of the use of greenery \\ and water as a natural space elements \\ improving local climates conditions
}

Streszczenie

Obecnie w prężnie rozwijających się miastach, obserwowany jest problem tzw. „Miejskiej Wyspy Ciepła”. Problem przegrzewających się przestrzeni zurbanizowanych wymusil niejako stosowanie rozwiazzań słuzących poprawie lokalnych mikroklsię na stałe w nowoczesne rozwiązania. Mają one istotny wpływ na projekty zwłaszcza te, które ubiegają się o certyfikaty energooszczędności oraz służą poprawie warunków życia lokalnych społeczności.

W wielu krajach, zastosowanie tych rozwiązań wiąże się też z kulturą $\mathrm{i}$ tradycja. Na przykład w Syrii wewnetrzne ogrody z elementami zbiorników wodnych na stałe wpisane są w historyczne rozwiązania. We Włoszech czy Francji, też trudno sobie wyobrazić przestrzenie miejskie czy obiekty bez zastosowania zieleni i wody. Zmieniający się klimat na Ziemi spowodowat, że iw Polsce coraz częściej stosuje zieleń i wodę w nowoczesnych rozwiązaniach.

\section{Abstract}

In many urbanized and developing cities we are observing the overheating of urban spaces commonly referred to as the Urban Heat Island effect. This pattern is forcing the development of innovative urban and architectural microclimate based solutions using both greenery and water to meet the energy efficiency certifications and to improve the living conditions of

The use of greenery and water elements in the design of cities and other public spaces has been commonplace in many used commonly in historic buildings and spaces in Syria. In Italy or France, it is difficult to imagine public places without the use of greenery and water. As a reaction to the mounting evidence of the effects of the Earth's climate change. Polish design-

Słowa kluczowe: zielen w architekturze, miejska wyspa ciepła, mikroklimat, woda w architekturze
Keywords: greenery in architecture, water in architecture, Urban Heat Island, microclimate

\section{Wstęp}

W coraz bardziej zaludnionym i zurbanizowanym wspótczesnym świecie ludzie pragną przebywać $w$ dogodnych dla sobie warunkach, dlatego dużą wagę przywiązuje się do zapewnienia jak największej, dobrze zbilansowane ilości terenów biologicznie czynnych w obszarach zur-

\section{Introducion}

With the increasing pattern of urbanization occurring globally we are witnessing populations searching for a balance between living conditions conducive to healthy lifestyles with the efficiency and access to opportunities located in urban areas. An important and banizowanych. Wprowadza się zieleń $\mathrm{i}$ wodę w rozwiąnikom zapewnić dobre warunki mikroklimatyczne. Wod i rośliny są niezbędne do normalnego funkcjonowania wszystkich stworzeń na ziemi w tym człowieka. Wodna jest podstawowym składnikiem naszego ciała, a jej niedobór może przyczynić się nawet do zgonu. Bez roślin nie zachodziłaby fotosynteza', proces w wyniku którego powstaje tlen, pierwiastek, bez którego człowiekowi trudno jest żyć. Jak zatem możemy wykorzystywać wode czy tereny zieleni w architekturze i urbanistyce? Jaki mają wpływ poprawę lokalnych mikroklimatów? Jak woda i zieleń przyczyniają się do niwelowania współ czynnika Miejskiej Wyspy Ciepłar?

W XXI wieku, zwłaszcza w krajach rozwinietych, nie możemy wyobrazić sobie naszej egzystencji bez otaczajacych nas elementów miejskiej architektury. To właśnie przestrzenie i budynki nadają wyraz i charakteryzuja dane miejsca, wsie czy miasta. Architektura i urbanistyka są takimi dziedzinami nauki, które tworzą obiekty oraz tereny tak istotne dla naszego życia. ${ }^{3}$ To one kreuja taczajaca nas przestrzeń, a architekci i urbaniści wykorzystują w swojej pracy całą swoją wiedzę, aby zapewnic nam najlepsze warunki do życia i pracy. "Jednym z najważniejszych zagadnień planowania urbanistycznego lest zapewnienie powierzchni biologicznie czynnych w zróżnicowanej wielkości i funkcji. Obszary rekreacyjne, parki publiczne oraz ogrody, wielofunkcyjne otwarte przestrzenie - mają zalety spoteczne, psychiczne i psychologiczne" Ponadto, zielone obszary takie jak parki miejskie mogą obnizyć temperature otoczenia nawet o 5 - $10^{\circ} \mathrm{C}$. Zarówno roślinność jak i woda maja wpływ na poziom wilgotności, a tym samym utrzymanie charakterystycznych parametrów poszczególnych ekosystemów wzbudzanie ruchu mas powietrza i efektu przewietrzania, penetracie promieni stonecznych oraz powstawinia barier akustycznych"

Istotnym elementem danej lokalizacji sa jej dobre wa lumi mikroklimatyczne. We wspold nicy dobry odbior pryestzen. Dopetnienien terenow zielen powy o byc woda, ḱć zapew in im mozlwosc rozopow. Jak wyjas widucyna Nyka w powszechnyc rozrostu. Jak wy jaśnia Lucyna Nyka "W powszechnym odbioze miasta granice pomiędzy lądem i woda pojmowan sa jako niezmienne. Wistocie jednak formy miast byty negocjowane względem wody, a linie przebiegu rzek kanałow wielokrotnie zmieniane. Obecnie, po latach zaniedbań woda jest doceniana jako komponent kom pozycji architektonicznych i krajobrazowych".

Każdy kraj, każde miasto charakteryzują się odmiennymi typowymi dla danej lokalizacji warunkami i klimatem a co za tym idzie innymi możliwosciami kształtowania przestrzeni. Kazda lokalizacja wymaga specjalnego podejscia i zastosowania w niej odpowiednich rozwiązan. W krajach basenu Morza Śródziemnego będziemy stosować inne rozwiazzania, niż chociazby w Polsce, a jesz- historic strategy has been to include large well-balanced often act as microclimates using greenery and water in a variety of spatial solutions to increase the quality of the local environments for the users. All creatures, including humans, rely on both water and plants for survival and proper functioning. Without water our body breakdow quickly leading to death. Without plants, there would not be photosynthesis' a process resulting in the production of oxygen which humans cannot live without.

How can we best use water and greenery in architecture and urban planning to improve local microclimates? How does water and greenery contribute to the leveling of the coefficient of the Urban Heat Island ${ }^{2}$ effect?

In the 21st century, especially in developed countries, we cannot imagine our existence without being surrounded by architectural and urban solutions. It is the urban space and their buildings that express and characterize the meaning of different places, villages and cities. Architecture and urban planning are special science areas that create objects, areas and spaces that are critically important for our lives ${ }^{3}$. and architects and planners use all of their knowledge to provide us with the best conditions for living and working. "One of the most important issues of urban planning is to provide biologically active areas with diversified size and function. Recreation areas, public parks and gardens, multifunctional open spaces - have social and psychologcal advantages. In addition, green areas such as urban parks can reduce the ambient temperature by as much as $5-10^{\circ} \mathrm{C}$. Both greenery and water have an impact on the level of humidity, and thus maintain the characteristic parameters of individual ecosystems, stimulate the movement of air masses and the ventilation effect, penetration of solar rays and the formation of acoustic barriers

To ensure that a project that has good perception of space, it is important that the given location has used its microclimate conditions well and that it should be associated with the use of green space and water elements that help the spaces grow. As Lucyna Nyka' explains, "I the general perception of the city, the boundaries between land and water are understood as unchangeable. In fact, the forms of cities were negotiated with respect to water, and the lines of rivers and canals changed many times. Now, after years of neglect, water is appreciated as a compositions."

Each country, each city is characterized by different conditions and climate typical for a given localization. Each location requires a special approach and the applicatio of appropriate solutions that gives many opportunities of space shaping. Whether your location is in the Mediterranean, Scandinavia or in Poland your solutions will be unique. This is dictated not only by design requirements, but also by culture and tradition and, most importantly the local climatic conditions. Therefore, the application of various types of projects with greenery and water reservoirs or even small water streams into 
cze inne w krajach skandynawskich. Jest to podyktowane nie tylko innymi wymagania inną kulturą, tradycją a przede wszystkim innymi warunkami klimatycznymi. Stosowanie zatem różnego rodzaju projektów z zastosowaniem terenów zieleni oraz wprowadzenia zbiorników wodnych czy małych cieków w architekture i urbanistyke musi być dostosowane do lokalnych potrzeb. Przyimowane rozwiazania maja istotny wpływ na poprawe lokalnie panuiacych mikroklimatów wplyw na poprawe lo Wyspy Ciepta.

\section{Czynniki klimatyczne}

Tworząc tereny zieleni oraz zbiorniki wodne należy pamiẹtać, iż każda ze stref na ziemi charakteryzuje sie innymi warunkami klimatycznymi, które wpływaja na dobór rozwiązań architektonicznych i urbanistycznych, oraz szaty roślinnej. Określając cechy poszczególnych stref, należy brać pod uwage czynniki klimatyczne wpływające na panujące na danym obszarze warunk są to m.in.:

poziom sredniorocznych temperatur

- ilość dni słonecznych

- ilość średniorocznych opadów

- siła i kierunek wiatrów.

Czynniki te wpływają na decyzje projektowe, określaja możliwość doboru odpowiedniej szaty roślinnej oraz o możliwości zastosowania wody w proponowanych rozwiązaniach. Innych rozwiązań i materiałów będziemy używać w klimacie, w którym występuje dużo dni słonecznych i temperatury powietrza są wysokie np. w klimacie zwrotnikowym suchym półwysep arabski (Syria), czy w klimacie śródziemnomorskim gdzie panuje gorace i suche lato z zimy sa łagodne ( $\mathrm{m}$.in. obszar Morza Śródziemnego) a jeszcze inaczej bedzie my projektować w Polsce gdzie mamy gtómnie klime my projel Soú w Polsce gdzé mán glownie klima potożone np. w krajach skandynawskich, gdzie ten thórych regionach panja wanki typowe dla stefy

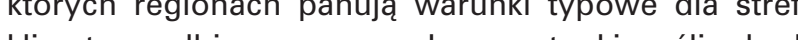
klimatu podbegu wymagaly pelnej eksozycji stonecznej i wysokich

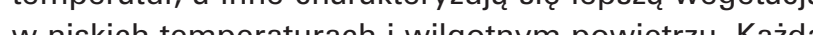
w niskich tempeaturach i wilgotnym powietrzu. Kazd ze stref charakteryzuje się innymi warunkami i przystoistotnym czynnikiem doboru odpowiedniej flory jest też

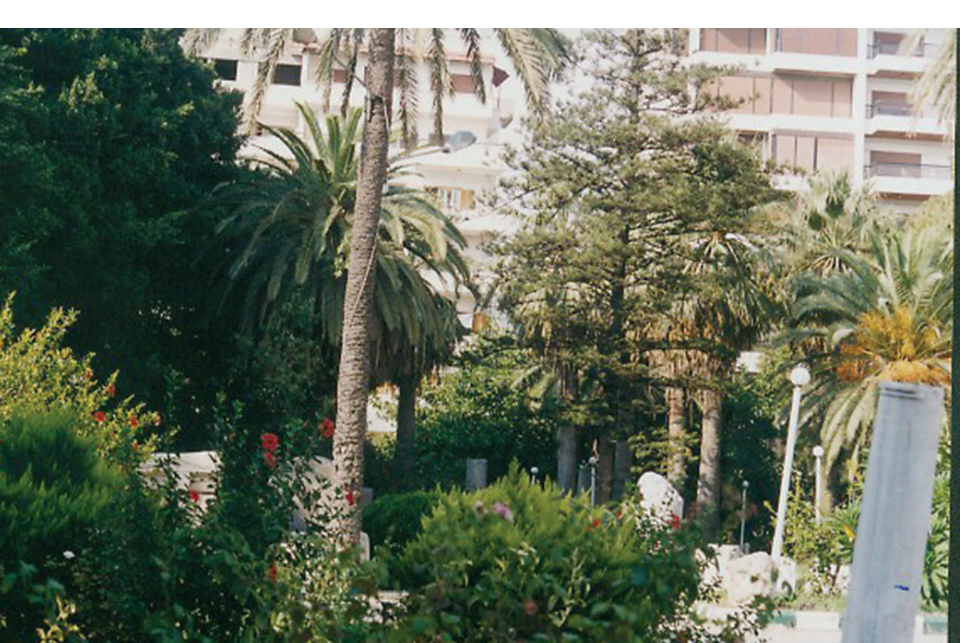

architecture and urban must be related to the needs of these factors into account have a significant impact on the improvement of the prevailing local microclimates, which contributes, among other things, to the effect of Urban Heat Islands.

\section{Climate factors}

When architects and urban planner are creating green areas and water reservoirs, they should remember that each of the earth zones are characterized by unique climatic conditions that affect the selection of architectura and urban solutions, including the selection of flora. When specifying the features of particular zones, on should take into account climatic factors affecting the conditions prevailing in a given area, these are, among others:

the level of annual temperatures

- number of sunny days

- amount of annual rainfall

- strength and directions of winds.

These factors affect the design decisions determining the possibility of choosing the right flora solutions and assists in identifying potential areas of using water in the proposed designs. The proposed projects depend on the climate, we would use one set of solutions and materias for climates with an abundance of sunny days and high air temperatures, for example in the tropica climate of the Arabian peninsula (Syria) a different set the Mediterraben plime where it has hot and set che Mot and dry (n) where we have manly a te a different way in Poland

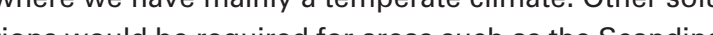
vion would be manty a tor areas such as the Scandinavan coun hes located in reglons wh condions typiwill reque All sir Will require full sun exposure and high temperatures, meanwhile olhors will have beter vegetation at low by differes condivin and by different conditions and plants that have adequately adapted to the area. Apart from sunlight, an important factor for appropriate flora is the possibility of irrigation. Water is needed not only for humans but also for plants to survive. A worrying phenomenon observed recently in many regions of the world is desertification, which unfortunately can contribute to problems with access to water.

II. 1. Jeden z parków miejskich w Lataki - Syria. Wykorzystano
tu różnego rodzaju lokalne rósiliny dla poprawy warunków mikroklimatycznych panujacych w mieście. Rośliny zapewniaja cien. cedry - rośliny typowe dla tej strefy klimatyczeje) Zdjeçecie $J . K$

plants were used here to in Lataki - Syria. Various types of loca viling in the city. Plants provide shade, which changes the temperature system and affect the air flow. (among others, various types
of amlm trees, flowering hibiscus, yew trees, cedars - typical plants
for this clim, mozliwośc irygacji danego obszaru. Woda, podobnie nia. Niepokojącym zjawiskiem obserwowanym ostatnio $\mathrm{w}$ wielu rejonach świata jest pustynnienie ${ }^{6}$, które niestety może przyczynić się do lokalnie wytupujących problemów z wodą

\section{Miejska Wyspa Ciepła}

Istotną role w codziennym życiu odgrywa słońce, które jest podstawowym źródtem światta w naszym uktadzie słonecznym. Bez niego i̇aden organizm żyiacy na neszym globie nie móglby istrieć. Promienie stoneczn a zbaurenie dle mos, oraz niezbed roślinom do a z bawienne da nus, oraz niezbedne rosinom do fotosyntezy. Niste w dobie sinie prosperujących miast w teyczynia sie do akumbij temperatur. Ciepto naprzyczyniają się do akumulacji tomperanty. Cleplo nagras następnie oddawane jest $w$ ciagu nocy do atmosfery, przyczyniając się do coraz powszechniejszego wystę powanie efektu Mlejskiej Wyspy Clepla. Akumulacja promieni słonecznych to tylko jedna z przyczyn występowania tego efektu. W równej mierze przyczyniają sie do tego, zła izolacja budynków i straty cieplne oraz zbyt mały udział lub całkowity brak trenów biologicznie czynnych w zurbanizowanych obszarach.

Próbując niwelowac problem MWC powinniśmy umieętnie kształtowac tereny miejskie zarowno od strony projektowej, ale też wykorzystując albedo' poszczególnych powierzchni. Inaczej bowiem akumulowane bądź odbijane są promienie słoneczne od powierzchn utwardzonych, a inaczej od wody czy terenów zielen (rys. 1.) Istotny jest zatem odpowiedni bilans terenów biologicznie czynnych w aglomeracjach miejskich Bez dobrej gospodarki terenami zieleni nie można mówić o dążeniu do poprawy warunków życia człowiek i zmianie lokalnie panujacych mikroklimatów. W wie lu krajach duży nacisk kładzie sie dziś na zagadnienia zrównoważonego rozwoju czy tworzenie miedzy innymi " infrastruktury".

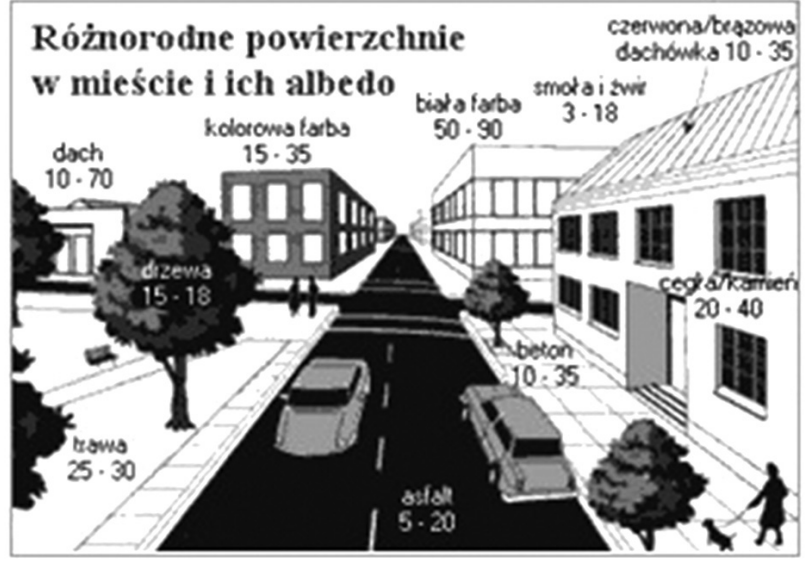

3. Urban Heat Island

The Sun plays an important role in our life as it provides organism on our planet to exist. Unfortunately, in high/y developed urban spaces, the sunrays also contribute to temperature accumulation. Heat is accumulated on different surfaces during the day and overnight the hea is given to the atmosphere which contributes to the increasing occurrence of the Urban Heat Island (UHI) effect. Accumulation of sunlight is only one of the reasons for this effect. Equally contributing to this are the poor insulation and thermal losses of buildings as well as the lack of adequate biologically active zones in urbanized areas.

In trying to eliminate the UHI problem, we should skillfully create urban areas both from the design side and, include in that, looking at the albedo' of individua surfaces. To avoid the sunrays from accumulating or reflecting on hardened surfaces we can look at the areas. (Fig. 1.) Therefore it is important to strike a balance between biologically active areas and urbanized ones to reduce the agglomeration within cities. Without a good green area economy, one cannot talk about improving the living conditions of a man and changing locally prevailing microclimates. Today in many countries the emphasis has been place on issues of sustainability to create "green cities" and cities with "green infrastructure".

4. Water and greenery in architectural and urban solutions

It is difficult to imagine life in modern society without dynamically developing urban areas but at the same time it is also difficult to live in spaces made entirely of concrete. "Greenery is one of the main factors determining the quality of life in urban spaces. This factor is recognized on a different scale, from a single tree in the courtyard of a downtown tenement house, a green wall covered traditionally with creepers or arranged with modern methods through the form of a square, park

il. 2. Rysunek ukazujacy wartości albedo poszczególnych po-
wierzchni występujących w mieście. żródło http://klimat.czn. uj.edu.pl
ill. 2. D rawing showing the albedo values of individual surfaces in 
4. Woda i zieleń w rozwiązaniach architektonicznych i urbanistycznych

Współczesnemu człowiekowi trudno wyobrazić sobie życie bez prężnie rozwijających się aglomeracji miejskich jednocześnie trudno jest też żyć $\mathrm{w}$ całkiem wybetonowanych przestrzeniach. „Jednym z głównych czynników decydujacych o jakości życia na terenach miejskich jest zieleń. Czynnik ten ujmuje sie w różnej skali od pojedynczego drzewa na dziedzincu śródmiejskiej kamienicy, zielona ściane pokryta tradycyinie pnaczami lub aranziowa zie wspótczesnymi metodami poprzez forme skweru, pan wspoczesnymi metody poprza forme skweru, parku, czon"s przyjazych miesk a przyjaznych mieszkancom, jest obechie jednym z ważniejszych nutow w projektowaniu urbaristycznym i architektonicznym. W wspolczesnych rozwiazanych wykorzystuje się nowe technologie $w$ celu podnoszenia standardów życia. W nowo projektowanych przestrzeniach publicz nych czy obiektach wprowadzą się rożnorodne teren biologicznieczynych aby zapewnic komfotuzykowani. W starych, historycznych zabudowaniach nie tylko w Europie zastosowanie zieleni i wody $w$ wielu wypadkach było związane z tradycją i kulturą danej cywilizacji czy narodu. Wprowadzenie tzw, „zielonej infrastruktury" w tkanke miejską sprzyja poprawie lokalnie panujących warunków. Drzewa i krzewy tworzą cien, przez co zmniejsza się temperatura, a różnica ciśnień występująca między nagrzanym a zacienionymi powierzchniami wywołuje przepływ powietrza. Woda znajdująca się $\mathrm{w}$ obrębie terenów zieleni zapewnia wilgotności powietrza, która przez odparowywanie obniża też temperaturę. W wysoce zurbanizowanych miastach rozwiązania te sprzyjają zmniejszeniu wystepowania efektu MWC oraz poprawią lokalny mikroklimat.

We wspófcześnie rozwijających sie miastach spotykamy różnego rodzaju wykorzystanie zieleni. W nowo powstajacych osiedluch czy dzielnicach tworzone sa pork skmery czy aleje. W wieluz tych rozwiazań do atkowymi skementami przestrzennymi sa fontanny, czy cieki wodne zape ni prace stata irygaje roślin. W krajach basen Morza Śródziemnego wprowadzanie fontann w obręb open green areas surrounding the city. ${ }^{\prime \prime}$ Creating urbanthe most important trends in urban and architectura design. New technologies are being used to raise living standards and in newly designed public spaces or facilties, various biologically active areas will be introduced to ensure the comfort of the user. In historical buildings, not only in Europe, the use of greenery and water in many cases was associated with the tradition and culture of a given civilization or nation.

The implementing of "green infrastructure" into the urban fabric favors the improvement of locally prevailing conditions. Adding trees and shrubs can create shadows that can reduce the temperature and create smal pressure difference between hot and shaded surfaces, which encourages airflow. Water located within greenery zones provides humidity for the air that also lowers the temperature through evaporation. In highly urbanized cities, these solutions are conducive to reducing the occurrence of the UHI effect and improve the local microclimate.

We find many different types of greening solutions being used in todays developing cities. As an example, in many new housing estates, districts or small cities, parks or squares are being created with this in mind. In many of these solutions the creation of fountain or watercourses are ensuring the constant irrigation of plants. In Mediterranean countries often fountains are introduced into green spaces to improve the local condition by altering the temperature within the spaces.. In Syria, a "courtyard or patio in multi-family and single-family buildings is one of the elements support ing the formation of an appropriate indoor climate. The fountains or plant pots with flowers and small shrubs located within its area have a direct impact on improving climatic conditions by lowering the temperature in the courtyard itself, as well as in the adjacen rooms. Both water and greenery accumulate low temperatures overnight and successively return during the day. The circulation of warm air, which is heavier and rises up, causes the inflow of lighter cold air into iil 5. Kanat w mieście Annecy na zachoddzie Francji, Wrodtü niego aleja

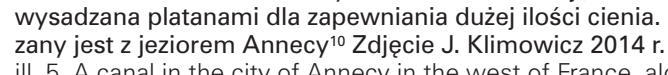

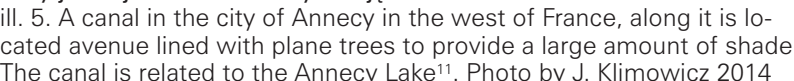

przestrzeni zielonych poprawia lokalnie panujące warunki. Zdecydowanie sprzyja to zmianie wystepujacych tam wysokich temperatur. W Syrii na przykład dziedziniec czy patio w zabudowie wielorodzinnej $i$ jednorodzinne

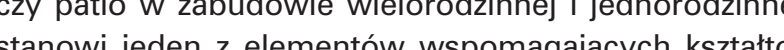
wanio odpon zstattowy. Lokalizowane w jego obrebie fontan cay donice

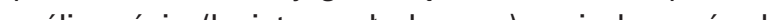
we ryw wpyw le

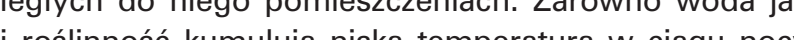
rosilinnośc kumulują niską temperatura w ciągu nocy i sukcesywnie oddaja w ciaggu dnia. Sam obieg cieplego powietrza, koore jest cięższe i unosi się w górę powoduje napływ lżejszego zimnego powietza do Whętrza dziedzińca zwłaszcza nocą i oddawane jest w dzień. ${ }^{\prime \prime}$ Zasada wymuszania przepływu powietrza wykorzystywana jest też $w$ wielu rozważaniach miejskich, gdzie wprowadza się wodę w postaci fontann i otaczających jest skwerów czy parków, ktore sprzyjają cyrkulacji powietrza.

Niektóre miasta mają możliwość wykorzystania natura-

nych cieków wodnych, kanałów lub rzek jako elementów

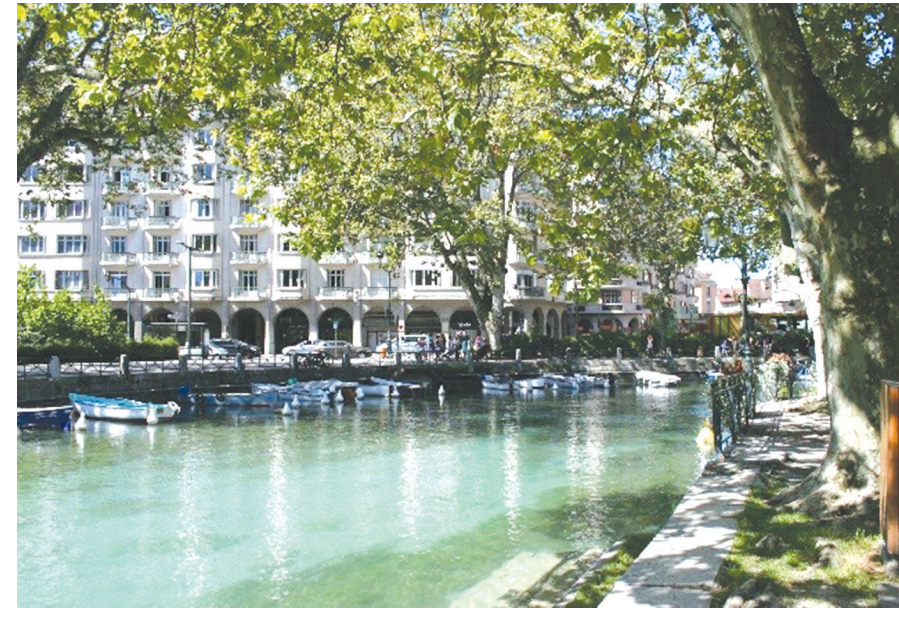

the interior of the courtyard, especially at night, and is given away during the day." " The principle of extracting air is also used in many urban considerations. where water is introduced in the form of fountains and there are squares or parks surrounding it, which are conducive to air circulation.

Some cities are located near natural watercourses such canals, streams or rivers, which can be uses as urban space natural elements. The watercourse adjust the good climate prevailing in a given city. Skillful management and use of greenery and water improves the citizens living conditions. These natural solutions are conducive in creation of parks, avenues or squares that both lowering the local prevailing temperatures, improving the air humidity and optimizing the occurrence of UH effect.

Within cities many solutions such as green walls and roofs are being used at the architectural level, which improves the microclimate surrounding, and within the building. In those solutions specially adapted plants are typically used for the best results in reducing the MWC effect. Green walls are also often used in interiors to improve the quality of the indoor conditions. These strate-

il. 3. Zdjeccie jednego z placów w Rawennie, Wykorzystanie zieleni oraz nowocześnie zaprojektowanej fontanny jako elementów zagospodaro-
wania placu. Zdjeccie J. Klimowicz 2017 ill. 3. One of the Ravenna's squares, the use of greenery and a modernly designed fountain as elements of the development of the square with
the historical surroundings. Photo of $J$. Klimowicz 2017

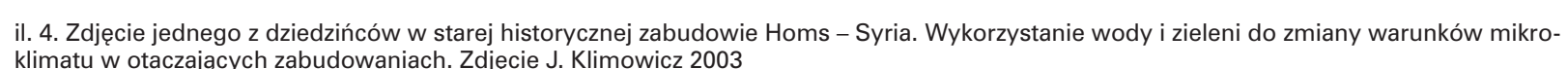

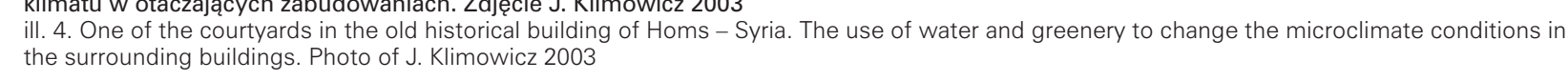

11. 6. Ściana zielona zaprojektowana przez Patrica Blance w Avinion we Francji. Ściana o powierzchni ok. $600 \mathrm{~m}^{2}$ tworzy efektowne wykończenie

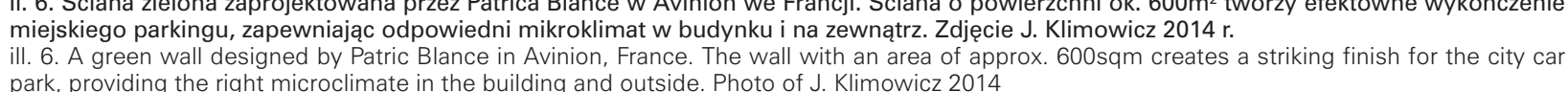

il. 7. Wykorzystanie zieleni i cieku wodnego jako elementów fragmentu ściany i dachu nad części budynku hotelowego w Ustroniu. Zdjęccie. ill. 7 . Use of greenery and watercourse as elements of a fragment of the wall and roof above the part of the hotel building in Ustroń. Photo. J. Kli-
mowicz 2016
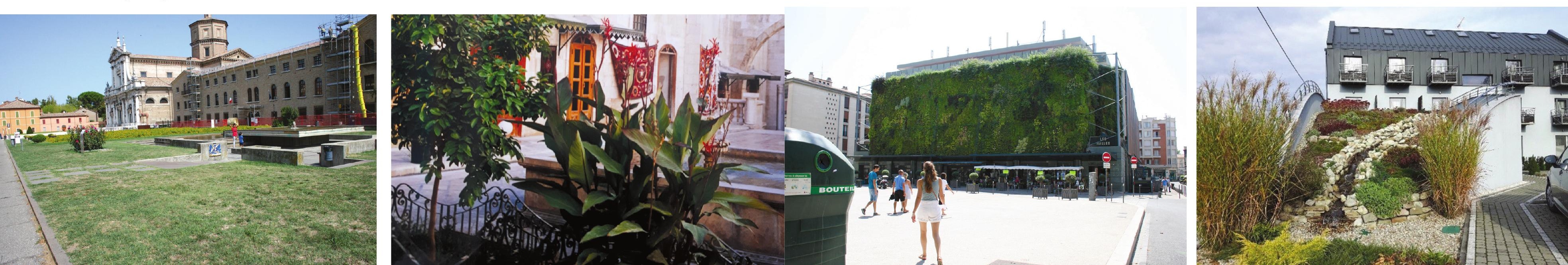
